DOI:10.22337/2587-9618-2018-14-3-161-168

\title{
MATHEMATICAL MODELING OF DIFFUSION PROCESSES OF MASS TRANSFER OF "FREE CALCIUM HYDROXIDE" DURING CORROSION OF CEMENT CONCRETES
}

\author{
Sergey V. Fedosov, Varvara Eu. Roumyantseva, Viktoriya S. Konovalova, \\ Svetlana A. Loginova \\ Ivanovo State Polytechnic University, Ivanovo, RUSSIA
}

\begin{abstract}
The paper presents a mathematical model of mass transfer in the processes of corrosion of the first type of cement concrete at the level of phenomenological equations for a closed reservoir-liquid system. A stepby-step transition to the recording of the boundary value mass conduction problem in dimensionless coordinates is shown. The solutions of the boundary value mass conduction problem for the region of large and small values of Fourier numbers are obtained.
\end{abstract}

Keywords: cement concrete, corrosion, mathematical model, mass transfer, concentration of "free calcium hydroxide"

\section{МАТЕМАТИЧЕСКОЕ МОДЕЛИРОВАНИЕ ДИФФУЗИОННЫХ ПРОЦЕССОВ МАССОПЕРЕНОСА «СВОБОДНОГО ГИДРОКСИДА КАЛЬЦИЯ» ПРИ КОРРОЗИИ ЦЕМЕНТНЫХ БЕТОНОВ}

\author{
С.В. Федосов, В.Е. Румянцева, В.С. Коновалова, С.А. Логинова \\ Ивановский государственный политехнический университет, г. Иваново, РОССИЯ
}

\begin{abstract}
Аннотация: В статье представлена математическая модель массопереноса в процессах коррозии первого вида цементных бетонов на уровне феноменологических уравнений для замкнутой системы «резервуаржидкость». Показан пошаговый переход к записи краевой задачи массопроводности в безразмерных координатах. Получены решения краевой задачи массопроводности для области больших и малых значений чисел Фурье.
\end{abstract}

Ключевые слова: цементный бетон, коррозия, математическая модель, массоперенос, концентрация «свободного гидроксида кальция»

\section{INTRODUCTION}

Durability of buildings and structures can be provided by the use of corrosion-resistant materials. Forecasting the service life of concrete and reinforced concrete structures is a complex analytical process [1]. In most cases, the main causes of damage are corrosion processes caused by adverse environmental effects.

Reliable prediction of durability of building structures is impossible without experimental analysis and theoretical developments [2] aimed at creating mathematical models of processes occurring at all stages of production and operation $[1,2]$.

One of the directions of the scientific school, which works fruitfully at Ivanovo state Polytechnic University, is the theoretical study and mathematical modeling of corrosion processes of concretes proceeding along the mechanisms of the first and second types [3-9]. To date, the authors of the article have developed a complex of mathematical models of 
corrosion processes in different environments, and proposed ways to combat corrosion destruction [6-9].

First of all, calcium oxide is responsible for the strength of concrete, which is part of the main minerals of Portland cement [1, 10]. The decrease in the content of "free calcium hydroxide", which is the main component that determines mass transfer, causes a change in the phase and thermodynamic equilibrium in the system, leads to the decomposition of the main components of the cement stone, and as a result, to the loss of the strength properties of concrete.

\section{MATHEMATICAL MODEL OF MASS TRANSFER IN CORROSION PROCESSES OF THE FIRST TYPE AT THE LEVEL OF PHENOMENOLOGICAL EQUATIONS FOR A CLOSED "RESERVOIR-LIQUID" SYSTEM}

Mass transfer in the "reservoir-liquid" system according to the first type of corrosion is determined by the boundary value problem of mass conductivity of the type $[3,4]$ :

$$
\frac{\partial C(x, \tau)}{\partial \tau}=k \frac{\partial^{2} C(x, \tau)}{\partial x^{2}}, \tau>0,0 \leq x \leq \delta .
$$

Initial condition:

$\left.C(x, \tau)\right|_{\tau=0}=C(x, 0)=C_{0}$.

Border conditions:

$$
\begin{aligned}
& \frac{\partial C(0, \tau)}{\partial x}=0, \\
& k \frac{\partial C(\delta, \tau)}{\partial x}=\beta\left[C_{e}(\tau)-C(\delta, \tau)\right] .
\end{aligned}
$$

where: $C(x, \tau)$ is concentration of "free calcium hydroxide" in concrete at a time $\tau$ at an arbitrary point with $\mathrm{x}$ coordinate, in terms of $\mathrm{CaO}, \mathrm{kg}$ $\mathrm{CaO} / \mathrm{kg}$ of concrete; $C_{0}(x)$ is concentration of "free calcium hydroxide" in concrete at the initial moment of time at any point with $\mathrm{x}$ coordinate, in terms of $\mathrm{CaO}, \mathrm{kg} \mathrm{CaO} / \mathrm{kg}$ of concrete; $k$ is mass conductivity coefficient in solid phase, $\mathrm{m}^{2} / \mathrm{s} ; \delta$ is wall thickness of the structure, $\mathrm{m}$.

The value of the equilibrium concentration on the surface of the solid $C_{e}$ is not constant, but depends on the concentration of the component in the liquid phase:

$$
\mathrm{C}_{\mathrm{e}}(\tau)=\mathrm{f}\left[\mathrm{C}_{\mathrm{liq}}(\tau)\right]
$$

The simplest form of this dependence is Henry's law [9]:

$$
C_{e}(\tau)=m C_{l i q}(\tau)
$$

where: $m$ is Henry's constant, $\mathrm{kg}$ of liquid / $\mathrm{kg}$ of concrete.

According to the law of mass conservation, the mass flow of substance emerging from the concrete surface should be equal to the amount of substance arriving in the liquid phase.

$$
-S \rho_{c o n} k \frac{\partial C(\delta, \tau)}{\partial x}=V_{l i q} \rho_{l i q} \frac{\partial C_{l i q}(\tau)}{\partial \tau}
$$

where: $S$ is internal surface of the tank, $\mathrm{m}^{2} ; V_{\text {liq }}$ is tank volume $\mathrm{m}^{3} ; \rho_{\text {con }}, \rho_{\text {liq }}$ are densities of concrete and liquid, respectively, $\mathrm{kg} / \mathrm{m}^{3}$.

To obtain generalized solutions suitable for qualitative analysis of corrosion processes, we introduce dimensionless variables of the form:

$$
\begin{gathered}
Z\left(\bar{x}, F o_{m}\right)=\frac{C_{0}-C(x, \tau)}{C_{0}}, \bar{x}=\frac{x}{\delta} \\
F o_{m}=\frac{k \tau}{\delta^{2}} .
\end{gathered}
$$

We transform the equation (1) with regard to (8): 
Mathematical Modelling of Diffusion Processes of Mass Transfer of "Free Calcium Hydroxide" During Corrosion of Cement Concretes

$$
\begin{aligned}
& \frac{\partial C\left[C_{0}-C(x, \tau)\right]}{\partial \tau \cdot C_{0}}= \\
= & k \frac{\partial^{2} C\left[C_{0}-C(x, \tau)\right]}{\partial x^{2} \cdot C_{0}} .
\end{aligned}
$$

This implies:

$$
\frac{\partial Z\left(\bar{x}, F o_{m}\right)}{\partial \tau}=k \frac{\partial^{2} Z\left(\bar{x}, F o_{m}\right)}{\partial x^{2}}
$$

Multiply by $\delta^{2}$ and divide by $k$ both parts of the equation:

$$
\frac{\partial Z\left(\bar{x}, F o_{m}\right) \delta^{2}}{\partial \tau \cdot k}=\frac{\partial^{2} Z\left(\bar{x}, F o_{m}\right) \delta^{2}}{\partial x^{2}} .
$$

In dimensionless coordinates, the boundary value problem (1)-(4) is transformed to the form $[5]$ :

$$
\begin{gathered}
\frac{\partial Z\left(\bar{x}, F o_{m}\right)}{\partial F o_{m}}=\frac{\partial^{2} Z\left(\bar{x}, F o_{m}\right)}{\partial \bar{x}^{2}}, \\
F o_{m}>0,0 \leq \bar{x} \leq 1
\end{gathered}
$$

Initial condition:

$$
Z(\bar{x}, 0)=0
$$

Border conditions:

$$
\begin{gathered}
\frac{\partial Z\left(0, F o_{m}\right)}{\partial \bar{x}}=0 . \\
\frac{1}{B i_{m}} \cdot \frac{\partial Z\left(1, F o_{m}\right)}{\partial \bar{x}}= \\
=\left[Z_{e}\left(F o_{m}\right)-Z\left(1, F o_{m}\right)\right] .
\end{gathered}
$$

where:

$$
B i_{m}=\beta \cdot \frac{\delta}{k}
$$

is Bio mass transfer criterion;

$$
F o_{m}=k \cdot \frac{\tau}{\delta^{2}}
$$

is Fourier mass transfer criterion.

We transform the equation (7) by multiplying the summands on the left by

$$
\frac{\delta}{\delta},
$$

and on the right by

$$
\begin{gathered}
\frac{\delta^{2}}{\delta^{2}}: \\
-S \rho_{c o n} k \frac{\partial\left[C_{0}-C(\delta, \tau)\right] \delta}{C_{0} \partial x \cdot \delta}= \\
=V_{l i q} \rho_{l i q} \frac{\partial C_{l i q}(\tau) \delta^{2}}{\partial \tau \cdot C_{0} \delta^{2}} .
\end{gathered}
$$

Assuming that the equilibrium in the system obeys Henry's law (6), we write:

$$
\begin{gathered}
\frac{S}{V} \cdot \frac{\rho_{c o n}}{\rho_{\text {liq }}} \cdot \frac{k}{\delta} \cdot \frac{\partial Z\left(0, F o_{m}\right)}{\partial \bar{x}}= \\
-\frac{\partial Z\left[C_{0}-m C_{l i q}(\tau)\right]}{m \partial\left(\frac{\tau}{\delta^{2}}\right) C_{0} \delta^{2}}= \\
=-\frac{\partial Z_{l i q}\left(F o_{m}\right)}{m \partial\left(\frac{\tau}{\delta^{2}}\right) \delta^{2}}
\end{gathered}
$$

Divide by $k$ :

$$
\begin{gathered}
\frac{S}{V} \cdot \frac{\rho_{\text {con }}}{\rho_{\text {liq }}} \cdot \frac{1}{\delta} \cdot \frac{\partial Z\left(1, F o_{m}\right)}{\partial \bar{x}}= \\
=-\frac{\partial Z_{l i q}\left(F o_{m}\right)}{m \partial\left(\frac{k \tau}{\delta^{2}}\right) \delta^{2}}
\end{gathered}
$$

The last expression denotes:

$$
Z_{l i q}\left(F o_{m}\right)=\frac{C_{0}-m C_{l i q}(\tau)}{C_{0}} .
$$


We denote that:

$$
K_{m}=\frac{m S \delta}{V_{l i q}} \cdot \frac{\rho_{c o n}}{\rho_{l i q}}=\frac{m G_{c o n}}{G_{l i q}}
$$

where: $K m$ is coefficient considering phase characteristics; $G_{c o n}$ is the mass of the concrete tank, kg; $G_{l i q}$ is the mass of liquid in the tank, $\mathrm{kg}$.

In the accepted variables equation (7) will take the form:

$$
-\frac{\partial Z_{l i q}\left(F o_{m}\right)}{\partial F o_{m}}=K_{m} \frac{\partial Z\left(1, F o_{m}\right)}{\partial \bar{x}}
$$

We transform the equation (6):

$$
\frac{C_{0}-C_{e}(\tau)}{C_{0}}=\frac{C_{0}-m C_{\text {liq }}(\tau)}{C_{0}} .
$$

In this case, the boundary value problem of mass conductivity will take the form:

$$
\frac{\partial Z\left(\bar{x}, F o_{m}\right)}{\partial F o_{m}}=\frac{\delta^{2} Z\left(\bar{x}, F o_{m}\right)}{\partial \bar{x}^{2}} .
$$

The initial and boundary conditions of expression (23) are expressions (13)-(15). In equation (15), $Z_{e}\left(F_{o_{m}}\right)$ is the same as $Z_{l i q}\left(F_{O_{m}}\right)$. The solution of the equation (23) obtained by the Laplace integral transformation takes the form $[5,6]$ :

$$
\begin{gathered}
\mathrm{Z}(\overline{\mathrm{x}}, \mathrm{s})=\operatorname{Ach}(\sqrt{\mathrm{s}} \overline{\mathrm{x}})+\mathrm{Bsh}(\sqrt{\mathrm{s}} \overline{\mathrm{x}}), \\
\frac{d Z(\bar{x}, s)}{\partial \bar{x}}=A \sqrt{s} \operatorname{sh}(\sqrt{s} \bar{x})+ \\
+B \sqrt{s} \operatorname{ch}(\sqrt{s} \bar{x}), \\
\frac{1}{B i_{m}}[A \sqrt{s} \operatorname{sh} \sqrt{s}]+\frac{K_{m}}{s}[A \sqrt{s} s h \sqrt{s}]= \\
=\frac{Z_{l i q}(0)}{s}-A \operatorname{ch} \sqrt{s},
\end{gathered}
$$

$$
\begin{gathered}
A= \\
=\frac{B i_{m} \sqrt{s} Z_{l i q}(0)}{s\left[s \operatorname{sh} \sqrt{s}+K_{m} \operatorname{sh} \sqrt{s}+B i_{m} \sqrt{s} \operatorname{ch} \sqrt{s}\right]} \\
Z(\bar{x}, s)= \\
=\frac{B i_{m} Z_{l i q}(0) \operatorname{ch}(\sqrt{s} \bar{x})}{s\left[\operatorname{ssh} \sqrt{s}+B i_{m} K_{m} \operatorname{sh} \sqrt{s}+B i_{m} \sqrt{s} \operatorname{ch} \sqrt{s}\right]}
\end{gathered}
$$

The final solution of the boundary value problem (23) for the region of large values of Fourier numbers (for $F_{O_{m}}>0,1$ ) has the form [5]:

$$
\begin{gathered}
Z\left(\bar{x}, F o_{m}\right)=\frac{Z(0)}{1+K_{m}}- \\
-2 B i_{m} Z_{l i q}(0) \sum_{n=1}^{\infty} \frac{\cos \left(\mu_{m} \bar{x}\right)}{\psi^{\prime}\left(\mu_{m}\right)} \exp \left(-\mu_{m}^{2} F o_{m}\right), \\
\psi^{\prime}\left(\mu_{\mathrm{m}}\right)=\sin \mu_{\mathrm{m}}\left[3 \mu_{\mathrm{m}}^{2}+\right. \\
\left.\mathrm{Bi}_{\mathrm{m}}\left(\mu_{\mathrm{m}}^{2}-\mathrm{K}_{\mathrm{G}} \mathrm{b}\right)\right]+ \\
\mu_{\mathrm{m}} \cos \mu_{\mathrm{m}}\left[\mu_{\mathrm{m}}^{2}-\left(\mathrm{Bi}_{\mathrm{m}} \mathrm{K}_{\mathrm{G}} \mathrm{b}+2\right)\right] .
\end{gathered}
$$

The characteristic equation for finding the roots of $\mu_{m}$ is:

$$
\operatorname{tg} \mu_{m}=\frac{B i_{m} \mu_{m}}{\mu_{m}^{2}-K_{m} B i_{m}}
$$

For the average concentration, we write:

$$
\begin{gathered}
Z_{\text {mid }}\left(F o_{m}\right)=\frac{Z_{\text {liq }}(0)}{1+K_{m}}- \\
-2 B i_{m} Z_{\text {liq }}(0) \sum_{n=1}^{\infty} \frac{\sin \mu_{m}}{\mu_{m} \psi^{\prime}\left(\mu_{m}\right)} \exp \left(-\mu_{m}^{2} F o_{m}\right),
\end{gathered}
$$


Mathematical Modelling of Diffusion Processes of Mass Transfer of "Free Calcium Hydroxide" During Corrosion of Cement Concretes

$$
\begin{aligned}
& Z_{l i q}\left(F o_{m}\right)= \\
& =Z_{l i q}(0)\{1 \\
& +2 B i_{m} K_{m} \sum_{n=1}^{\infty} \frac{\sin \mu_{m}}{\mu_{m} \psi^{\prime}\left(\mu_{m}\right)}\left[\operatorname { e x p } \left(-\mu_{m}^{2} F o_{m}\right.\right. \\
& -1]\} .
\end{aligned}
$$

In cases where the condition $F_{O m} \leq 0,1$ is satisfied, it is advisable to obtain solutions using hyperbolic functions for large values of arguments (small Fourier numbers).

The final solution of the equation (23) for the region of small values of Fourier numbers has the form:

$$
\begin{gathered}
\frac{Z\left(\bar{x}, F o_{m}\right)}{Z_{l i q}(0)}= \\
=-\frac{B i_{m}}{\sqrt{B i_{m}^{2}-4 K_{m}}} \sum_{i=1}^{2}(-1)^{i} \exp \left[-a_{i}(1\right. \\
\left.-\bar{x})+a_{i}^{2} F o_{m}\right] \operatorname{erfc}\left(\frac{1-\bar{x}}{2 \sqrt{F o_{m}}}\right. \\
\left.-a_{i} \sqrt{F o_{m}}\right), \quad-a \pm \sqrt{D} \\
\frac{a_{i}=\frac{2}{Z_{l i q}\left(F o_{m}\right)}}{\mathrm{Z}_{\mathrm{mid}}\left(\mathrm{Fo} \mathrm{o}_{\mathrm{m}}\right)}=\int_{0}^{1} \mathrm{Z}(\overline{\mathrm{x}}, \mathrm{Fo}) \mathrm{d} \overline{\mathrm{x}} \\
-\frac{K_{m} B i_{m}}{\sqrt{B i_{m}^{2}-4 K_{m} B i_{m}}} \sum_{i=1}^{2}(-1)^{i+1}\left\{2 \sqrt{\frac{F o_{m}}{\pi}}\right. \\
\left.+a_{i} \int_{0}^{F o_{m}} \exp \left(a_{i}^{2} F o_{m}\right) \operatorname{erfc}\left(-a_{i} \sqrt{F o_{m}}\right) d F o_{m}\right\}
\end{gathered}
$$

The obtained expressions allow to calculate the concentration fields of the transferred component along the thickness of the structure, to find the average concentration at any time, and to determine the value of the concentration of the "target" component in the liquid phase. Some results of calculations [5-7] are shown in Figures 1 and 2.

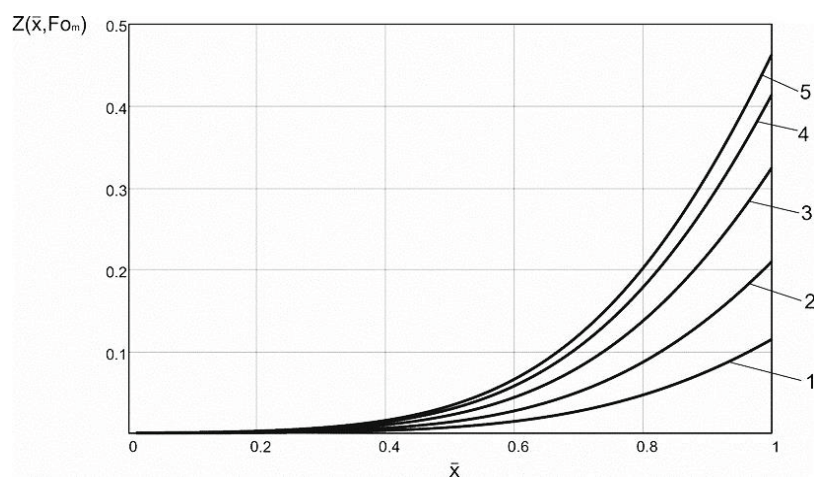

Figure 1. Profiles of the dimensionless concentrations on the thickness of the concrete at $F_{O_{m}}=0.05$ at various values of $B i_{m}: 1-0.5$;

$$
2-1 ; 3-1.75 ; 4-2.5 ; 5-3 \text {. }
$$

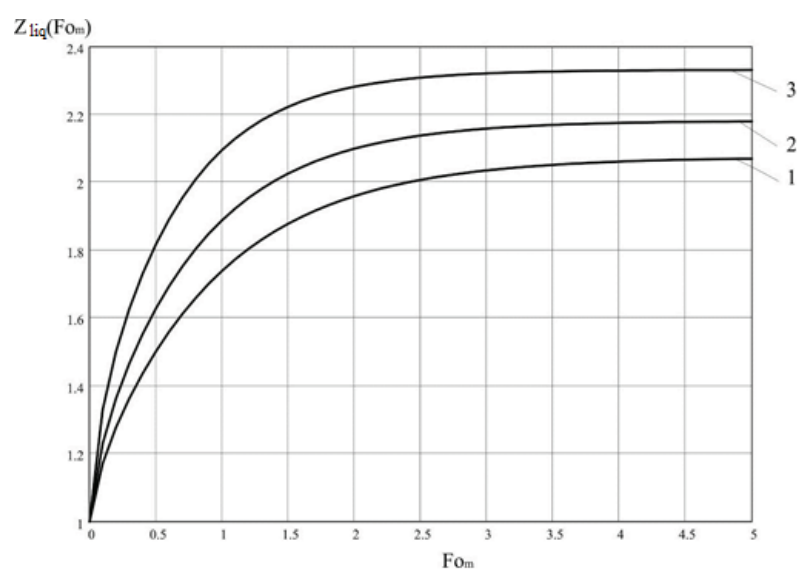

Figure 2. Concentration of the transferred component in the liquid phase at $F_{O_{m}}=0 \div 5$; $K m=0.1 ; B i_{m}: 1-0.5 ; 2-1 ; 3-1.5$.

A necessary condition for the implementation of calculations is the availability of data on static and kinetic characteristics of the process, which can be obtained only on the basis of experimental studies.

\section{CONCLUSION}

Development of mathematical models is impossible without a clear understanding of the mechanism of the processes, experimental data characterizing the influence of various factors 
on the kinetics and dynamics of processes and verification of the correctness of the forecast methodology in full-scale conditions $[6,8]$.

The joint analysis of the results of numerical and experimental studies confirms the adequacy of the developed mathematical models of mass transfer in the systems under study and makes it possible to use the developed mathematical models and the proposed methods for calculating the mass transfer process at the corrosion of the first and second types on real objects.

\section{REFERENCES}

1. Moskvin V.M. Korroziya Betona [Corrosion of Concrete]. Moscow, Gosstrojizdat, 1952, 342 pages.

2. Stepanova V.F., Sokolova S.E., Polushkin A.L. Problemy Dolgovechnosti Betonnyh i Zhelezobetonnyh Konstrukcij v Sovremennom Stroitel'stve [Problems of Durability of Concrete and Reinforced Concrete Structures in Modern Construction] // Bulletin of SIC Construction, 2017, No. 1(12), pp. 126-133.

3. Fedosov S.V., Rumyanceva V.E., Kas'yanenko N.S., Krasil'nikov I.V. Teoreticheskie i Ehksperimental'nye Issledovaniya Processov Korrozii Pervogo Vida Cementnyh Betonov pri Nalichii Vnutrennego Istochnika Massy [Theoretical and Experimental Studies of Corrosion Processes of the First Type of Cement Concrete in the Presence of an Internal Source of Mass] // Building materials. 2013. No. 6. pp. 44-47.

4. Rumyanceva V.E., Loginova S.A. Matematicheskoe Modelirovanie Korrozionnyh Processov Betona i Zhelezobetona [Mathematical Modeling of Corrosion Processes of Concrete and Reinforced Concrete]. // Issues of modern science and practice. University of V.I. Vernadsky, 2015, No. 1(55), pp. 235-244.
5. Fedosov S.V., Fedosova N.L., Rumyanceva V.E., Krasil'nikov I.V. Issledovanie Diffuzionnyh Processov Massoperenosa pri Zhidkostnoj Korrozii Pervogo Vida Cementnyh Betonov [Investigation of Diffusion Processes of Mass Transfer During Liquid Corrosion of the First Type of Cement Concretes]. // Proceedings of High Schools. Chemistry and Chemical Technology, 2015, Vol. 58, No. 1, pp. 99-104.

6. Fedosov S.V., Rumyanceva V.E., Krasil'nikov I.V., Konovalova S.V., Karavaev I.V. Opredelenie Resursa Bezopasnoj Ehkspluatacii Konstrukcij iz Betona, Soderzhashchego Gidrofobiziruyushchie Dobavki [Determination of Safe Service Life of Structures Made of Concrete Containing Hydrophobic Additives]. // Proceedings of high schools. Technology of the textile industry, 2017, No. 6(372), pp. 268-276.

7. Fedosov S.V., Rumyanceva V.E., Krasil'nikov I.V., Loginova S.A. Issledovanie Vliyaniya Processov Massoperenosa na Nadezhnost' i Dolgovechnost' Zhelezobetonnyh Konstrukcij, Ehkspluatiruemyh v Zhidkih Agressivnyh Sredah [Investigation of the Influence of Mass Transfer Processes on the Reliability and Durability of Reinforced Concrete Structures Operated in Liquid Aggressive Media]. // Building materials, 2017, No. 12, pp. 52-57.

8. Fedosov S.V., Rumyanceva V.E., Konovalova S.V., Karavaev I.V. ZHidkostnaya Korroziya Betonov v Srede s Razlichnoj Stepen'yu Agressivnosti [Liquid Corrosion of Concrete in the Environment with Various Degree of Aggressiveness] // Bulletin of Civil Engineers, 2017, No. 4(62), pp. 113-118.

9. Fedosov S.V., Rumyanceva V.E., Konovalova S.V. Issledovanie Processov Korrozionnoj Destrukcii Zhelezobetonnyh Izdelij $\mathrm{V}$ Agressivnyh Sredah s Hloridionami [Study of the Processes of a 
Mathematical Modelling of Diffusion Processes of Mass Transfer of "Free Calcium Hydroxide" During Corrosion of Cement Concretes

Corrosion Destruction of Reinforced Concrete Products in Aggressive Environments Containing Chloride Ions]. // Bulletin of civil engineers, 2016, No. 5(58), pp. 61-67.

10. Liang Ming-Te, Shien-Min Lin. Mathematical Model and Applications for Concrete Carbonation. // Journal of Marine Science and Technologic, 2003, Vol. 11, No. 1, pp. 20-30.

\section{СПИСОК ЛИТЕРАТУРЫ}

1. Москвин В.М. Коррозия бетона. - М.: Госстройиздат, 1952. - 342 с.

2. Степанова В.Ф., Соколова С.E., Полушкин А.Л. Эффективные способы вторичной защиты для повышения долговечности зданий и сооружений. // Вестник НИЦ Строительство, 2017, №1(12), c. 126-133.

3. Федосов С.В., Румянцева B.E., Касьяненко Н.С., Красильников И.В. Теоретические и экспериментальные исследования процессов коррозии первого вида цементных бетонов при наличии внутреннего источника массы. // Строительные материалы, №6, 2013, с. 44-47.

4. Румянцева В.Е., Логинова С.А. Математическое моделирование коррозионных процессов бетона и железобетона. // Вопросы современной науки и практики. Университет им. В.И. Вернадского, 2015, №1(55), с. 235-244.

5. Федосов С.В., Федосова Н.Л., Румянцева В.Е., Красильников И.В. Исследование диффузионных процессов массопереноса при жидкостной коррозии первого вида цементных бетонов. // Известия вузов. Химия и химическая технология, 2015, Том 58, Вып. 1, с. 99-104.

6. Федосов С.В., Румянцева В.Е., Красильников И.В., Коновалова С.В., Караваев И.В. Определение ресурса безопасной эксплуатации конструкций из бетона, содержащего гидрофобизирующие добавки. // Известия вузов. Технология текстильной промышленности, 2017, №6(372), с. 268276.

7. Федосов С.В., Румянцева В.E., Красильников И.В., Логинова С.А. Исследование влияния процессов массопереноса на надежность и долговечность железобетонных конструкций, эксплуатируемых в жидких агрессивных средах. // Строительные материалы, 2017, №12, с. 52-57.

8. Федосов C.B., Румянцева B.E., Коновалова С.В., Караваев И.В. Жидкостная коррозия бетонов в среде с различной степенью агрессивности. // Вестник гражданских инженеров, 2017, №4(62), c. 113-118.

Sergey V. Fedosov, Full Member of the Russian Academy of Architecture and Construction Sciences, Professor, Doctor of Technical Sciences, head of the Department of "Technosphere safety" Ivanovo State Polytechnical University; 153037, Russia, Ivanovo region, Ivanovo, St. $8^{\text {th }}$ March, 20;

phone +7(4932) 32-85-40; fax +7(4932) 37-19-42;

E-mail: fedosov-academic53@mail.ru.

Varvara E. Roumyantseva, Advisor to the Russian Academy of Architecture and Construction Sciences, Professor, Doctor of Technical Sciences, Director of the Institute of information technologies and natural Sciences and Humanities, head of the Department of nanotechnology, physics and chemistry, Ivanovo State Polytechnical University; 153037, Russia, Ivanovo region, Ivanovo, St. $8^{\text {th }}$ March, 20;

phone +7(4932) 41-75-09; +7(906)617-17-84;

E-mail: varrym@gmail.com.

Viktoriya S. Konovalova, Candidate of Technical Sciences, senior lecturer of the Department of nanotechnology, physics and chemistry, Ivanovo State Polytechnical University; 153037, Russia, Ivanovo region, Ivanovo, St. $8^{\text {th }}$ March, 20;

phone+7(910)997-02-68; e-mail: kotprotiv@yandex.ru.

Svetlana A. Loginova, assistant Professor of the Department of nanotechnology, physics and chemistry, 
Ivanovo State Polytechnical University; 153037, Russia, Ivanovo region, Ivanovo, St. $8^{\text {th }}$ March, 20;

phone +7(906)617-12-27;

E-mail: s179066171227@yandex.ru.

Федосов Сергей Викторович, академик Российской академии архитектуры и строительных наук (РАAСН), профессор, доктор технических наук, заведующий кафедрой «Техносферная безопасность» Ивановского государственного политехнического университета; 153037, Россия, Ивановская область, г. Иваново, ул. 8 Марта, д. 20; тел. +7(4932) 32-85-40; факс +7(4932) 37-19-42;

E-mail: fedosov-academic53@mail.ru.

Румянцева Варвара Евгеньевна, советник Российской академии архитектуры и строительных наук (РАAСН), профессор, доктор технических наук, директор Института информационных технологий и естественно-гуманитарных наук, заведующая кафедрой нанотехнологий, физики и химии Ивановского государственного политехнического университета; 153037, Россия, Ивановская область, г. Иваново, ул. 8 Марта, д. 20; тел. +7(4932) 41-75-09; +7(906)617-17-84; e-mail: varrym@gmail.com.

Коновалова Виктория Сергеевна, кандидат технических наук, старший преподаватель кафедры нанотехнологий, физики и химии Ивановского государственного политехнического университета; 153037 , Россия, Ивановская область, г. Иваново, ул. 8 Марта, д. 20; тел. +7(910)997-02-68;

E-mail: kotprotiv@yandex.ru.

Логинова Светлана Андреевна, ассистент кафедры нанотехнологий, физики и химии Ивановского государственного политехнического университета; 153037, Россия, Ивановская область, г. Иваново, ул. 8 Марта, д. 20; тел. +7(906)617-12-27;

E-mail: s179066171227@yandex.ru. 